\title{
THE IMPACT OF METABOLIC SYNDROME ON RADIAL ARTERY DIAMETERS
}

\author{
${ }^{1}$ Marshell Luntungan \\ ${ }^{1}$ Andhi Purabaya \\ ${ }^{2}$ Bambang Budiono \\ ${ }^{1}$ Janry A. Pangemanan \\ ${ }^{1}$ Reginald L. Lefrandt \\ ${ }^{1}$ Departement of Cardiology and Vascular Medicine Faculty of Medicine \\ University of Sam Ratulangi Manado \\ ${ }^{2}$ Heart and Vascular Center Awal Bros Hospital Makassar \\ Email: ac31lz_27@yahoo.com
}

\begin{abstract}
Abstrak: Dewasa ini akses arteri radialis telah digunakan secara luas pada intervensi koroner transkateter. Pada pasien sindroma metabolik (MetS) yang berisiko tinggi diabetes melitus tipe 2 (DMT2), proses aterosklerosis sistemik telah memengaruhi struktur arteri radialis. Penelitian ini bertujuan untuk menentukan faktor-faktor yang berpengaruh terhadap diameter arteri radialis pada pasien MetS. Penelitian ini bersifat prospektif dan dilaksanakan di Laboratorium Kateterisasi Rumah Sakit Awal Bros Makassar sejak 1 Januari sampai dengan 15 Ferbuari 2013 (45 hari). Hasil penelitian memperlihatkan bahwa dari 40 pasien yang menjalani prosedur angiografi koroner melalui akses transradial, 22 di antaranya (55\%) menyandang MetS. Rerata diameter arteri radialis pada kelompok pasien MetS dan non-MetS ialah 2,13 mm dan $2 \mathrm{~mm}$. Lingkar pinggang, lingkar pergelangan, kolesterol total, HDL-C, dan trigliserida berbeda secara bermakna antara kedua kelompok. Analisis statistik dengan regresi linear menunjukkan korelasi bermakna antara diameter arteri radialis terhadap usia saja $(\mathrm{r}=0,185 ; \quad P<0,05)$. Simpulan: Terdapat korelasi bermakna antara diameter arteri radialis dengan usia, dan tidak dengan faktor lainnya.
\end{abstract}

Kata kunci: diameter arteri radialis, sindroma metabolik.

\begin{abstract}
Nowadays, radial artery access is widely used as a route for transcatheter coronary interventions. Albeit, in metabolic syndrome (MetS) patients who are at high risks of developing type 2 diabetes mellitus, the systemic atheroslerosis process may have influenced the radial artery structures. This study aimed to determine factors that might influence the radial artery diameters in MetS patients. This was a prospective study conducted in the Catheterization Laboratory Awal Bros Hospital Makassar from 1st January until 15th Febuary 2013 (45 days). The results showed that in this study there were 40 consecutive patients who underwent coronary angiography procedures using the transradial apporach, of these 22 patients (55\%) were with MetS. The mean radial artery diameters in MetS and non-MetS patients were $2.13 \mathrm{~mm}$ and $2 \mathrm{~mm}$, respectively. The waist circumference, wrist circumference, total cholesterol, HDL-C, and triglyceride were significantly different between the two groups. The data were analyzed by using a linear regression resulting in radial artery diameters (RAD) which were significantly and positively correlated only with age among the MetS subjects $(\mathrm{r}=0.185, P<0.05)$. Conclusion: Among the metabolic syndrome patients radial artery diameters were only significantly correlated to ages, and not other factors.
\end{abstract}

Keywords: radial artery diameter, metabolic syndrome. 
Over more than 32 years ago the radial artery was first used by Carpentier as an alternative conduit for coronary artery bypass grafting. ${ }^{1,2}$ Since then, the versality of the radial artery has extended beyond its use as an alternative site of access for cardiac catheterization. ${ }^{2}$

Previous studies have demonstrated the feasibility of using the radial artery as a route for transcatheter coronary interventions. The major advantage of this strategy over conventional transfemoral and/or transbrachial techinques includes the lower risk of access sites related to complications, which may be attributed to the unique anatomy of the radial artery. First, because the radial artery is located superficially, hemostasis can be easily achieved by a local compression. Second, no large veins or nerves exist near the radial artery, which minimizes the chances of injuries of those structures. Lastly, collateral blood supply via the palmar arch usually precludes the occurence of hand ischemia even when the radial artery becomes occluded by thrombosis. ${ }^{3,4}$

It is well known that metabolic syndrome (MetS) is a clustering of the cardiovascular $(\mathrm{CV})$ risk factors associated with an increased risk of developing cardiovascular diseases (CVD) and diabetes mellitus. It has also been associated with early vascular alterations, explaining, at least in part, the high CV risk. A variety of stimuli, including inflammation, hemodynamic changes, and injuries can modify the artery diameters. ${ }^{5}$

Regarding the complexity of MetS related to cardiovascular risk factors, our study was carried out to determine factors that might influence the radial artery diameters in MetS patients.

\section{METHODS}

A total of forty consecutive patients who underwent coronary angiography in the Catheterization Laboratory Awal Bros Hospital Makassar by using the transradial approach from 1st January 2013 to 15th Febuary 2013 were enrolled in this study.
All subjects were reviewed for their medical histories and the presence of eventual risk factors of cardiovascular diseases. Physical exami-nations to assess blood pressures (BP) and anthropometric measurements were also perfomed. The body mass index (BMI) was calculated as weight (in $\mathrm{kg}$ ) divided by the square of height (in $\mathrm{m} 2$ ). The blood glucose, creatinine, total cholesterol, high density lipoprotein cholesterol, and triglyceride were measured by using standard laboratory techniques.

Patients categorized as having the metabolic syndrome were those who fulfilled the NCEP ATP III MetS criteria for the Asian population. The radial artery diameters were measured by using the quantitive angiographic analalyses.

\section{Metabolic syndrome}

The categories of MetS patients were based on NCEP ATP III MetS criteria for the Asian population, who fulfilled any 3 of 5 criteria: 1) Increased waist circumference $90 \mathrm{~cm}$ in males and $80 \mathrm{~cm}$ in females; 2) Elevated triglyceride 150 $\mathrm{mg} / \mathrm{dL}$ or under drug treatment for elevated triglycerides; 3) Reduced HDL-C <40 $\mathrm{mg} / \mathrm{dL}$ in males and $<50 \mathrm{mg} / \mathrm{dL}$ in females, or under drug treatment for reduced HDL$\mathrm{C}$; 4) Elevated blood pressure (BP): 150 $\mathrm{mmHg}$ systolic blood pressure (SBP) or 85 $\mathrm{mmHg}$ diastolic blood pressure (DBP), or under anti-hypertensive drug treatment in patients with histories of hypertension; 5) Elevated fasting glucose $100 \mathrm{mg} / \mathrm{dL}$ or under drug treatment for elevated glucose. ${ }^{6,7}$

\section{Arteriography of the arm}

A 5Fr (length $7 \mathrm{~cm}$, Merit Medical US) sheat was inserted into the right radial artery under local anesthesia for transradial coronary angiography (CA) and then followed by percutaneus coronary intervention (PCI). The patient was given a mixture of Heparin $5000 \mathrm{IU}$, isosorbide dinitrate $300 \mathrm{Ug}$ and $5 \mathrm{cc}$ of normal saline in one syringe, injected into the radial artery. 
Arteriography of the arm was perfomed before coronary angiography. Four $\mathrm{mL}$ of contrast was injected from the inserted sheat to acquire the arm arteriography. Angiography was perfomed on the entire radial and ulnar artery using an anteroposterior projection.

\section{Quantitive angiographic analysis}

Quantitive angiographic analysis was performed with an automated edge detection system (quantitive vascular analysis, xcelera r3. 1L1 3.1.1.422-2009, Philips, the Netherlands) by the operator. The radial artery outer luminal diameter of the sheat was used as the calibration reference for quantitive angiographic analysis. The inner luminal diameter of the radial artery was measured at one point after the sheat.

\section{Statistical analysis}

Data were reported as the mean of \pm SD. A t-test was perfomed to compare the means of continous variables among groups with and without MetS. We performed a linear regression analysis with the radial artery diameter as the dependent variable, while age, height, weight, BMI, wrist circumference, waist circumference, total cholesterol, LDL, and blood glucose the independent variables. Significant differences were assumed to be present at a $P$-value < 0.05. Ninety-five percent confidence intervals were reported. All analyses were perfomed by using the SPSS 21.0 for Macintosh.

\section{RESULT}

There were 40 patients enrolled in this study, 22 of whom (55\%) had MetS. The clinical, biochemical, anthropometric, and radial diameter characteristics of the subjects with and without MetS are shown in Table 1.

The mean radial artery diameters in MetS and Non-Mets subjects were 2.13 $\mathrm{mm}$ and $2 \mathrm{~mm}$, respectively. The waist circumference, wrist circumference, total cholesterol, HDL-C, and triglyceride were
Table 1. Clinical, biochemical, anthropometric and RAD characteristics of the subjects with or without Mets

\begin{tabular}{|c|c|c|c|}
\hline Variables & $\begin{array}{c}\text { MetS } \\
(n=22) \\
(\text { mean } \pm \\
\text { SD })\end{array}$ & $\begin{array}{c}\text { N-MetS } \\
(n=18) \\
(\text { mean } \pm \\
\text { SD })\end{array}$ & $p$ \\
\hline Age (years) & $61 \pm 9.9$ & $56.2 \pm 8.7$ & 0.11 \\
\hline Male & 19 & 12 & \\
\hline Female & 3 & 6 & \\
\hline Weight (kg) & $76.45 \pm 5$ & $68.2 \pm 11$ & 0.06 \\
\hline Height (cm) & $165.54 \pm 6$ & $162.7 \pm 7$ & 0.18 \\
\hline BMI (kg/m2) & $27.73 \pm 5.16$ & $25.6 \pm 3.5$ & 0.16 \\
\hline $\begin{array}{l}\text { Waist circumference } \\
(\mathrm{cm})\end{array}$ & $\begin{array}{c}104.25 \pm 17 \\
14\end{array}$ & $89 \pm 9.5$ & $<0.05$ \\
\hline $\begin{array}{l}\text { Wrist circumference } \\
(\mathrm{cm})\end{array}$ & $18 \pm 2.28$ & $16.4 \pm 1.1$ & $<0.05$ \\
\hline $\mathrm{SBP}(\mathrm{mmHg})$ & $144.5 \pm 19.7$ & $135 \pm 24.7$ & 0.22 \\
\hline $\mathrm{DBP}(\mathrm{mmHg})$ & $81.5 \pm 8.6$ & $78.8 \pm 8$ & 0.31 \\
\hline $\begin{array}{l}\text { Total Cholesterol } \\
(\mathrm{mg} / \mathrm{dL})\end{array}$ & $213.3 \pm 58$ & $176.6 \pm 32.5$ & $<0.05$ \\
\hline HDL-C (mg/dL) & $38 \pm 7$ & $50 \pm 11$ & $<0.05$ \\
\hline $\mathrm{TG}(\mathrm{mg} / \mathrm{dL})$ & $164.3 \pm 54.7$ & $128.9 \pm 38$ & $<0.05$ \\
\hline $\begin{array}{l}\text { Fasting blood glucose } \\
(\mathrm{mg} / \mathrm{dL})\end{array}$ & $137.7 \pm 59.5$ & $108.5 \pm 45.8$ & 0.09 \\
\hline RAD ( mm) & $2.13 \pm 0.41$ & $2.01 \pm 0.38$ & 0.37 \\
\hline $\mathrm{UAD}(\mathrm{mm})$ & $1.78 \pm 0.28$ & $1.7 \pm 0.3$ & 0.89 \\
\hline
\end{tabular}

significantly different between the two groups. The data were analyzed by using a linear regression resulting in radial artery diameters (RAD) which were significantly and positively correlated only with age among the MetS subjects $(\mathrm{r}=0.185, P<$ 0.05) (Figure 2).

Figure 2. Linear regression analysis between RAD and age $(\mathrm{r}=0.185, P<0.05)$.

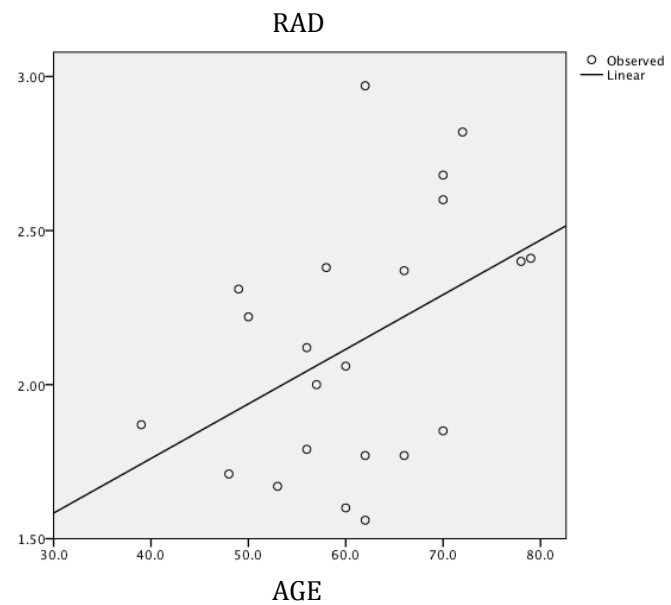




\section{DISCUSSION}

Extensive literature has discussed the role of MetS as a risk factor for cardiovascular diseases (CVD). This study showed that the MetS prevalence was high in this population $(55 \%)$. There was a significant difference in wrist circumference between the MetS and non-MetS subjects. A recent study in Iran with 1,709 participants showed that there was an association between wrist circum-ference and cardio-metabolic risk factors. ${ }^{8}$

In the statistical analysis using linear regression, we found that the variance in RADs was correlated with age and the presence of Mets, while in non-Mets subjects all the findings were not significantly correlated. Montalcini et al. ${ }^{5}$ found that the brachial artery diameters were larger in postmenopausal women with a metabolic syndrome.

A prolonged exposure to $\mathrm{CV}$ risk factors alters the adaptive mechanism that will produce structural changes in arterial walls. The structural changes in the arteries include an increase in collagen contents and calcification of the tunica media; creases and breakages of elastic lamallae; and migration and accumulation of vascular myocytes into the arterial walls. Albeit, the exact underlying mechanism is still unclear.

There are some hypotheses about these findings. MetS is characterized by an activation of the renin-angiotensin system, an important humoral factor involved in regulating the turn over of extracellular matrix proteins, and a strong regulator of matrix metalloproteinase and tissue inhibitor of metalloproteinase, as well as of cytokines released by adipose tissues. ${ }^{9}$ The metalloproteinase (MMP) itself has been suspected of being implicated in vascular remodelling; in fact, it is known that this MMP is involved in human and experimental aortic aneurysms, ${ }^{10}$ probably by the breakdown of the extracellular matrix (ECM). In MetS, circulating concentrations of pro-MMP-9, MMPs-9, MMP-8, TIMP-1, ${ }^{11}$ and MMP-3 were increased in older people. ${ }^{12}$
There are some limitations in our study: the number of samples is too small and the samples are only from a single centre study. However, there remain fewer studies about radial artery diameter in metabolic syndrome patients, espe-cially in the Asian population thus far. Further studies involving larger samples and multicentres are needed to support this study.

\section{CONCLUSION}

Among the metabolic syndrome patients in the Catheterization Laboratory Awal Bros Hospital Makassar the radial artery diameters were only significantly correlated to ages among the other factors.

\section{ACKNOWLEDGEMENT}

We would like to thank the director of Awal Bros Hospital Makasssar who permitted us to carry out our study in this hospital.

Presented as a Free Paper - Oral Presentation at the 22nd Annual Scientific Meeting of Indonesian Heart Association (Asmiha), Jakarta, Indonesia, April 5-7, 2013.

\section{REFERENCES}

1. Loh JY, Nakao M, Tan WD, Lim CH, Tan YS, Chua YL. Factors influencing radial artery size. Asian Cardiovasc Thorac Ann. 2007;15:324-6.

2. Ashraf T, Panhwar Z, Habib S, Memon MA, Shamsi F, Arif J. Size of radial and ulnar artery in local population. J Pak Med Assoc. 2010;60(10):817-9.

3. Yokoyama N, Takeshita S, Ochiai M, Koyama Y, Hoshino S, Isshiki T, et al. Anatomic variations of the radial artery in patients undergoing transradial coronary intervention. Catheter Cardiovasc Interv. 2000;49(4):357-62.

4. Kotowycz MA, Dzavik V. Radial artery patency after transradial catheterization. Circ Cardiovasc Interv. 2012;5:127-33.

5. Montalcini T, Gorgone G, Gazzaruso C, Garzaniti A, Pujia A. Large brachial artery diameter and metabolic syndome 
in postmenopausal Women. Atherosclerosis. 2010;210(2):458-60.

6. Grundy SM, Brewer HB, Cleeman JI, Smith SC Jr, Lenfant C. Definition of metabolic syndrome: Report of the National Heart, Lung, and Blood Institute/American Heart Association Conference on Scientific Issues Related to Definition. Circulation. 2005; 109(3):433-8.

7. Grundy SM, Cleeman JI, Daniel SR, Donato KA, Eckel RH, Frangklin BA, et al. Diagnosis and management of the metabolic syndrome: An American Heart Association/National Heart, Lung, and Blood Institute Scientific Statement. Circulation. 2005;112: 2735-52.

8. Amini A, Soltanian N, Iraj B, Askari G, Ebneyamin S, Ghias $M$, et al. Association of wrist cirumference with cardio-metabolic risk factors. J Pak Med Assoc. 2012;62(3 Suppl 2):S34-6.

9. Scuteri A, Najjar SS, Orru M, Usala G, Piras MG, Ferrucci L, et al. The central arterial burden of the metabolic syndrome is similar in men and women: the SardiNIA Study. Eur Heart J.
2010;31(5):602-13.

10. Thompson RW, Holmes DR, Mertens RA, Liao S, Botney MD, Mecham RP, et al. Production andlLocalization of 92-kilodalton gelatinase in abdominal aortic aneurysms. An elastolytic metalloproteinase expressed by aneurysm-infiltrating macrophages. J Clin Invest. 1995;96:318-26.

11. Goncalves FM, Jacob-Ferreira AL, Gomes VA, Casella-Filho A, Chagas AC, Marcaccini AM, et al. Increased circulating levels of matrix metalloproteinase (MMP)-8, MMP-9, and proinflammatory markers in patients with metabolic syndrome. Clin Chim Acta. 2009;403(1-2):173-7.

12. Marín-García J, Goldenthal MJ, Moe GW. Aging of the vasculature and related system. In: Marín-García J, Goldenthal MJ, Moe GW, editors. Aging and Heart: A Post-genomic View [monograph online]. New Jersey: Springer US, 2008; p.154. Available from: http://link.springer.com/book/ 10.1007/978-0-387-74072-0. 